\title{
Clonal profile, virulence and resistance of Staphylococcus aureus isolated from sheep milk
}

\author{
Katheryne Benini Martins ${ }^{1}$, Patricia Yoshida Faccioli-Martins ${ }^{1}$, \\ Danilo Flávio Moraes Riboli ${ }^{1}$, Valéria Cataneli Pereira ${ }^{1}$, Simone Fernandes ${ }^{2}$, \\ Aline A. Oliveira ${ }^{2}$, Ariane Dantas ${ }^{2}$, Luiz Francisco Zafalon ${ }^{3}$, \\ Maria de Lourdes Ribeiro de Souza da Cunha ${ }^{1}$ \\ ${ }^{1}$ Departamento de Microbiologia e Imunologia, Instituto de Biociências, Universidade Estadual Paulista \\ "Júlio de Mesquita Filho", Botucatu, SP, Brazil. \\ ${ }^{2}$ Departamento de Produção Animal, Faculdade de Medicina Veterinária e Zootecnia, Universidade \\ Estadual Paulista "Júlio de Mesquita Filho", Botucatu, SP, Brazil. \\ ${ }^{3}$ Embrapa Pecuária Sudeste, Empresa Brasileira de Pesquisa Agropecuária, São Carlos, SP, Brazil.
}

Submitted: November 1, 2013; Approved: October 7, 2014

\begin{abstract}
The objective of this study was to characterize the clonal profile, virulence factors and antimicrobial resistance, particularly oxacillin resistance, of Staphylococcus aureus isolated from sheep milk. Milk samples were collected from all teats for the California Mastitis Test (CMT), somatic cell count, identification of S. aureus, investigation in these strains of genes encoding toxins (sea, seb, sec, sed, tst), biofilm (icaA, icaC, icaD, bap), leukocidin (luk-PV) oxacillin resistance by mecA gene detection and susceptibility testing (12 antibiotics). Messenger RNA expression was evaluated by RT-PCR in isolates carrying toxin and biofilm genes. Biofilm formation was also evaluated phenotypically by adherence to polystyrene plates. The clonal profile of $S$. aureus was investigated by pulsed-field gel electrophoresis. A total of 473 milk samples were collected from 242 animals on three farms and 20 $S$. aureus strains were isolated and none carried the $m e c A$ gene. The two $s e c$ gene-positive isolates and the isolates carrying the tst and $l u k-P V$ genes were positive by RT-PCR. Staphylococcus aureus isolated from the three flocks studied showed high susceptibility to the drugs tested and none was biofilm producer, indicating that biofilm formation was not a virulence factor causing infection by these strains. The typing of $17 \mathrm{~S}$. aureus isolates revealed the presence of a common clone on the three farms studied, and the presence and expression of the sec and tst genes in one strain of this clone suggest the possible acquisition of virulence genes by this clone, a fact that is important for animal health and food hygiene.
\end{abstract}

Key words: mastitis, sheep, Staphylococcus aureus, antibiotic resistance, virulence factors.

\section{Introduction}

Mastitis is an inflammation of the mammary gland which is characterized by physical, chemical and microbiological alterations in milk and tissue abnormalities. Furthermore, the disease is associated with premature culling of ewes with udder abnormalities and reduced weight gain of lambs. In the study of Moroni et al. (2007), the weight gain of lambs nursing dams without mastitis was higher than that of animals nursing ewes with subclinical mastitis. Among the latter, lambs nursing dams with subclinical infection caused by $S$. aureus showed lower weight gain than those nursing dams with mastitis caused by other infectious agents such as coagulase-negative staphylococci, streptococci, and Gram-negative bacteria.

In small ruminants such as sheep, coagulase-negative staphylococci are the microorganisms most frequently iso-

Send correspondence to K.B. Martins. Departamento de Microbiologia e Imunologia, Instituto de Biociências, Universidade Estadual Paulista "Júlio de Mesquita Filho", Botucatu, SP, Brazil. E-mail: katheryne_bm@yahoo.com.br. 
lated from cases of subclinical mastitis (Bergonier et al., 2003; Vautor et al., 2009), whereas S. aureus can cause clinical and subclinical mastitis (Contreras et al., 2007). S. aureus was the microorganism most frequently isolated from milk of Awassi sheep with subclinical mastitis, accounting for $39 \%$ of all isolates, followed by Streptococcus spp. (25\%), Escherichia coli (19.6\%), and coagulase-negative staphylococci (17.9\%) (Al-Majali and Jawabreh, 2003). Santos et al. (2007) studied the clinical aspects and milk characteristics of 10 Santa Inês sheep with clinical mastitis after experimental inoculation of their mammary glands with $S$. aureus. The results showed a reduction in milk production and fat content, in addition to alterations in the physicochemical properties of milk. After treatment, although the animals had recovered from the disease, the function of their mammary glands was completely lost.

Mastitis caused by $S$. aureus can result in long-term infection and can become chronic, with a low rate of cure and consequent loss of milk production (Sabour et al., 2004), since this microorganism possesses different virulence factors that contribute to its persistence in mammary tissue (Santos et al., 2003). Different virulence factors such as enterotoxins, leukocidins and biofilms (Peacock et al., 2002) are important since they contribute to aggravation of the disease and are a matter of public health. Biofilm formation permits adherence and colonization of the mammary gland epithelium (Otto, 2008), leukocidin causes tissues necrosis and leukocyte destruction, and enterotoxins can cause food poisoning (Argudín et al., 2010).

In addition to virulence, a major concern in the control of mastitis is resistance of the etiological agents to antibiotics. Therapeutic success is compromised by the growing number of strains resistant to drugs used indiscriminately in veterinary medicine. Staphylococcal resistance to methicillin is associated with the acquisition of the staphylococcal cassette chromosome mec (SCCmec), a resistance island consisting of the structural gene, mecA. $S$. aureus strains carrying this gene are classified as methicillin (oxacillin)-resistant $S$. aureus (MRSA). These strains are frequently resistant to most antimicrobial agents, including aminoglycosides, macrolides, chloramphenicol, tetracycline, and fluoroquinolones (Wang et al., 2008; Kumar et al., 2010).

Therefore, the objective of the present study was to characterize the clonal profile, virulence factors and antibiotic resistance of $S$. aureus isolated from raw milk of sheep with subclinical mastitis.

\section{Materials and Methods}

\section{Origin of the isolates}

Milk samples were collected from each teat of 242 sheep belonging to the following experimental flocks: 37 from the flock of Instituto de Zootecnia, Nova Odessa, 150 from the flock of Embrapa Pecuária Sudeste, São Carlos, and 55 from the Edgardia Farm, Faculdade de Medicina Veterinária e Zootecnia, Botucatu. All facilities are located in the State of São Paulo, Brazil. The flocks from São Carlos and Nova Odessa were Santa Inês sheep and those from Botucatu were Bergamacia sheep. Milk samples were collected from all animals for microbiological tests for the isolation of $S$. aureus.

Screening for subclinical cases was performed immediately before the collection of milk samples for the microbiological diagnosis of mastitis by the California Mastitis Test (CMT) according to the technique of Schalm and Noorlander (1957). Samples were also collected for somatic cell count (SCC) into flasks containing bronopol for counting in an electronic Somacount 300 (Bentley Instruments $\left.{ }^{\circledR}\right)$. Mammary glands with a positive reaction in the $\mathrm{CMT}$ or $\mathrm{SCC}>3.0 \times 10^{5}$ cells $/ \mathrm{mL}$ milk (McDougall et al., 2001) and that were bacteriologically positive were classified as subclinical mastitis.

\section{Isolation and identification of $S$. aureus}

The milk samples were cultured on blood agar at $37^{\circ} \mathrm{C}$ for $72 \mathrm{~h}$. Suspected bacterial colonies were stained by the Gram method for inspection of morphology. Colonies characterized as Gram-positive cocci were submitted to catalase and coagulase tests. The genus Staphylococcus was differentiated from Micrococcus based on the oxidation and fermentation of glucose, resistance to bacitracin (0.04 U), and susceptibility to furazolidone (100 mg). $S$. aureus was identified based on the fermentation of maltose, trehalose, and mannitol (Cunha et al., 2004).

\section{Antimicrobial susceptibility testing}

Twenty $S$. aureus isolates were submitted to in vitro susceptibility testing by the disk diffusion method according to the guidelines of the Clinical Laboratory Standard Institute (2012). The following 12 antibiotics were tested: rifampicin $(5 \mu \mathrm{g})$, linezolid $(30 \mu \mathrm{g})$, vancomycin $(30 \mu \mathrm{g})$, clindamycin $(2 \mu \mathrm{g})$, erythromycin $(15 \mu \mathrm{g})$, penicillin (10 UI), oxacillin (1 $\mu \mathrm{g})$, cefoxitin $(30 \mu \mathrm{g})$, tetracycline $(30 \mu \mathrm{g})$, gentamicin $(10 \mu \mathrm{g})$, ciprofloxacin $(5 \mu \mathrm{g})$, and cotrimoxazole $(25 \mu \mathrm{g})$.

\section{DNA extraction and amplification by PCR for detection of the mecA, biofilm (icaADBC and bap) and exotoxin genes (sea, seb, sec, sed, tst and luk-PV)}

Total nucleic acid was extracted from Staphylococcus spp. strains cultured on blood agar, inoculated individually into brain-heart infusion (BHI) broth, and incubated for $24 \mathrm{~h}$ at $37^{\circ} \mathrm{C}$. The Illustra ${ }^{\circledR}$ kit (GE Healthcare) was used for extraction. Briefly, staphylococcal cells were first digested with $10 \mathrm{mg} / \mathrm{mL}$ lysozyme and $20 \mathrm{mg} / \mathrm{mL}$ proteinase K. Next, $500 \mu \mathrm{L}$ lysis solution was added and the mixture was centrifuged at 5,000 $\mathrm{g} g$ for $1 \mathrm{~min}$. The supernatant was 
transferred to a column and centrifuged at $11,000 \times \mathrm{g}$ for $1 \mathrm{~min}$. The liquid part was discarded and $500 \mu \mathrm{L}$ lysis solution was again added to the column. After centrifugation at $11,000 \times \mathrm{g}$ for $1 \mathrm{~min}$ and discarding the liquid part, $500 \mu \mathrm{L}$ washing solution was added and the column was centrifuged at $11,000 \times g$ for $3 \mathrm{~min}$. Next, the column was transferred to a $1.5-\mathrm{mL}$ tube and $200 \mu \mathrm{L}$ Milli-Q water (Millipore, Eschborn, Germany) heated to $70{ }^{\circ} \mathrm{C}$ was used for elution. The samples were centrifuged at 5,000 $\mathrm{x} g$ for $1 \mathrm{~min}$ and the column was discarded. The extracted DNA was stored at $-20^{\circ} \mathrm{C}$. For detection of the mecA, biofilm (icaADBC, bap) and exotoxin genes (sea, seb, sec, sed, tst and $l u k-P V$ ), the primers shown in Table 1 and the parameters recommended by the respective authors were used: Murakami et al. (1991), Rohde et al. (2007), Arciola et al. (2005), Cucarella et al. (2001), Johnson et al. (1991), and Lina et al. (1999).

The agarose gels were prepared at a concentration of $2 \%$ in $1 \mathrm{X}$ TBE, stained with SYBR Safe DNA Gel Stain ${ }^{\circledR}$ (Invitrogen), and visualized under a UV transilluminator.
Reactions that amplified fragments larger than 1,000 bp were submitted to electrophoresis on $0.8 \%$ agarose gel.

\section{Confirmation of the expression of virulence factors}

The expression of the genes encoding enterotoxin A, B, C, D or toxic shock syndrome toxin 1 (TSST-1), biofilm genes (icaADBC and bap) and $l u k-P V$ in the $S$. aureus isolates in which these genes were amplified by PCR was confirmed by RT-PCR as described below.

\section{RNA extraction}

Total RNA was extracted from $S$. aureus cultured on blood agar, inoculated individually into BHI broth, and incubated for $24 \mathrm{~h}$ at $37^{\circ} \mathrm{C}$. The Illustra RNAspin Mini RNA kit was used for extraction according to manufacturer instructions. For this purpose, $200 \mu \mathrm{L}$ of the $S$. aureus culture was transferred to a sterile $1.5-\mathrm{mL}$ Eppendorf tube and centrifuged at 10,000 $\mathrm{x} g$ for $1 \mathrm{~min}$. Next, the supernatant was discarded, $100 \mu \mathrm{L}$ TE containing $2 \mathrm{mg} / \mathrm{mL}$ lysozyme was added, and the mixture was incubated for $10 \mathrm{~min}$ at $37^{\circ} \mathrm{C}$. For cell lysis, $350 \mu \mathrm{L}$ RA1 buffer was added together with

Table 1 - Primers used for PCR.

\begin{tabular}{|c|c|c|c|}
\hline Gene & 5'-3' Nucleotide sequence & Amplification product (bp) & Reference \\
\hline \multirow[t]{2}{*}{$i c a A$} & TGG CTG TAT TAA GCG AAG TC & 669 & Rohde et al., 2007 \\
\hline & CCT CTG TCT GGG CTT GAC C & & \\
\hline \multirow[t]{2}{*}{$i c a C$} & TAA CTT TAG GCG CAT ATG TTT & 400 & Arciola et al., 2005 \\
\hline & TTC CAG TTA GGC TGG TAT TG & & \\
\hline \multirow[t]{2}{*}{$i c a D$} & ATG GTC AAG CCC AGA CAG AG & 198 & Arciola et al., 2005 \\
\hline & CGTGTTTTCAACATTTAATGCAA & & \\
\hline \multirow[t]{2}{*}{$i c a B$} & CTGATCAAGAATTTAAATCACAAA & 302 & Arciola et al., 2005 \\
\hline & AAA GTC CCA TAA GCC TGT TT & & \\
\hline \multirow[t]{2}{*}{ bap } & CCC TAT ATC GAA GGT GTA GAA TTG CAC & 971 & Cucarella et al., 2001 \\
\hline & GCT GTT GAA GTT AAT ACT GTA CCT GC & & \\
\hline \multirow[t]{2}{*}{ bap } & CCC TAT ATC GAA GGT GTA GAA TTG CAC & 971 & Cucarella et al., 2001 \\
\hline & GCT GTT GAA GTT AAT ACT GTA CCT GC & & \\
\hline \multirow[t]{2}{*}{ sea } & TTG GAA ACG GTT AAA ACG AA & 120 & Johnson et al., 1991 \\
\hline & GAA CCT TCC CAT CAA AAA CA & & \\
\hline \multirow[t]{2}{*}{ seb } & TCG CAT CAA ACT GAC AAA CG & 478 & Johnson et al., 1991 \\
\hline & GCA GGT ACT CTA TAA GTG CC & & \\
\hline \multirow[t]{2}{*}{$\mathrm{sec}$} & GAC ATA AAA GCT AGG AAT TT & 257 & Johnson et al., 1991 \\
\hline & AAA TCG GAT TAA CAT TAT CC & & \\
\hline \multirow[t]{2}{*}{ sed } & CTA GTT TGG TAA TAT CTC CT & 317 & Johnson et al., 1991 \\
\hline & TAA TGC TAT ATC TTA TAG GG & & \\
\hline \multirow[t]{2}{*}{ tst } & ATG GCA GCA TCA GCT TGA TA & 350 & Johnson et al., 1991 \\
\hline & TTT CCA ATA ACC ACC CGT TT & & \\
\hline \multirow[t]{2}{*}{$l u k-\mathrm{PVL}$} & ATC ATT AGG TAA AAT GTC TGG ACA TGA TCC & 433 & Lina et al., 1999 \\
\hline & GCA TCA ATT GTA TTG GAT AGC AAA AGC & & \\
\hline \multirow[t]{2}{*}{ mecA } & ATC GAT GGT AAA GGT TGG & 533 & Murakami et al., 1991 \\
\hline & AGT TCT GCA GTA CCG GAT TTG & & \\
\hline
\end{tabular}


$3.5 \mu \mathrm{L} \beta$-mercaptoethanol. The solution was applied to RNAspin Mini Filter units and centrifuged at 11,000 x $g$ for $1 \mathrm{~min}$. The filters were discarded after centrifugation. For adjustment of the binding conditions, $350 \mu \mathrm{L} \mathrm{70 \%} \mathrm{ethanol}$ was added to the filtrate and the mixture was transferred to an RNAspin Mini Column and centrifuged at 8,000 x $g$ for $30 \mathrm{~s}$. For adsorption of RNA to the membrane, $350 \mu \mathrm{L}$ membrane desalting buffer was added and the mixture was centrifuged at $11,000 \times \mathrm{g}$ for $1 \mathrm{~min}$. The samples were then washed in two steps. First, $600 \mu \mathrm{L}$ RA3 buffer was added and the column was centrifuged at $11,000 \times \mathrm{g}$ for $1 \mathrm{~min}$. For the second wash, $250 \mu \mathrm{L}$ RA3 buffer was added and the column was centrifuged at $11,000 \mathrm{x} g$ for $2 \mathrm{~min}$. The column was then transferred to a new 1.5-mL Eppendorf tube for the elution of RNA. For this purpose, $45 \mu \mathrm{L}$ RNA-free water containing $5 \mu \mathrm{L}$ guard RNA was added and the column was centrifuged at $11,000 \times \mathrm{g}$ for $1 \mathrm{~min}$. DNase treatment for complete elimination of possible DNA residues consisted of the addition of $2 \mu \mathrm{L}$ buffer and $2 \mu \mathrm{L}$ DNase and incubation of the mixture for $1 \mathrm{~h}$ at $37^{\circ} \mathrm{C}$. Next, $2 \mu \mathrm{L}$ Stop DNase was added and the mixture was incubated for $10 \mathrm{~min}$ at $65^{\circ} \mathrm{C}$ for the inhibition of DNase. The extracted RNA was immediately stored at $-80^{\circ} \mathrm{C}$.

\section{Preparation of $c D N A$}

Two mixtures were prepared (Mix 1 and Mix 2). For Mix 1, $14 \mu \mathrm{L}$ RNA (divided into aliquots and treated with DNase), $1 \mu \mathrm{L}$ dNTP, and $4 \mu \mathrm{L}$ nuclease-free water were used (extraction kit). For Mix 2, $4 \mu \mathrm{L}$ 5X First-Strand Buffer, $1 \mu \mathrm{L}$ DTT $(0.1 \mathrm{M})$, and $1 \mu \mathrm{L}$ SuperScript III $(200 \mathrm{U} / \mu \mathrm{L})$ were used. Mix 1 was incubated in a thermocycler for $5 \mathrm{~min}$ at $65^{\circ} \mathrm{C}$, removed from the thermocycler, and immediately put on ice for approximately $5 \mathrm{~min}$. Next, Mix $2(6 \mu \mathrm{L})$ was added and the sample was again placed in the thermocycler and the program was continued with 30 cycles at $65^{\circ} \mathrm{C}$ for $5 \mathrm{~min}, 25^{\circ} \mathrm{C}$ for $5 \mathrm{~min}, 50^{\circ} \mathrm{C}$ for $60 \mathrm{~min}$, $70{ }^{\circ} \mathrm{C}$ for $15 \mathrm{~min}$, and finished at $20^{\circ} \mathrm{C}$. The cDNA was then frozen at $-80{ }^{\circ} \mathrm{C}$.

\section{PCR amplification of $c D N A$}

The cDNA obtained was submitted to RT-PCR to determine the expression of toxin and biofilm genes using the primers described in Table 1. The amplified products were visualized by electrophoresis as described in item 2.4.

\section{Investigation of biofilm formation by adherence to polystyrene plates (Christensen et al., 1985) modified by Oliveira and Cunha (2010)}

The method of biofilm formation on culture plates proposed by Christensen et al. (1985) and modified by Oliveira and Cunha (2010) was used. This method is based on the spectrophotometric determination of the optical density of the adherent material produced by the bacteria.
Cultures grown in TSB for $24 \mathrm{~h}$ and subsequently diluted $1: 1$ in TSB prepared with $2 \%$ glucose were used. The tests were carried out in 96-well flat-bottom plates (Costar, model 3599, Corning). The wells were filled in quadruplicate with $200 \mu \mathrm{L}$ of the diluted culture. The following international reference strains were included in all tests: $S$. aureus ATCC 29213 (biofilm producer) as positive control and ATCC 33591 (non-producer) as negative control, and S. epidermidis ATCC 35983 (biofilm producer) as positive control and ATCC 12228 (non-producer) as negative control, as well as sterile TSB. The plates were incubated for $24 \mathrm{~h}$ at $37^{\circ} \mathrm{C}$. After this period, the content of each well was carefully aspirated with a multichannel pipette and the wells were washed four times with $200 \mu \mathrm{L}$ phosphatebuffer saline, $\mathrm{pH}$ 7.2. The plates were dried at room temperature for $1 \mathrm{~h}$. Next, the wells were stained with $2 \%$ crystal violet for one minute, the volume was aspirated, and excess dye was removed by washing the plates with distilled water using a multichannel pipette. The plates were then dried at room temperature for $60 \mathrm{~min}$ and optical density was read in a Labsystem Multiskan EX microplate reader equipped with a 540-nm filter. The strains were classified as negative when the cut-off value corresponded to the classification of non-adherent, and as positive when the cut-off value corresponded to the classification of weakly or strongly adherent.

\section{Pulsed-field gel electrophoresis (PFGE)}

PFGE of the $S$. aureus isolates was done according to a modification of the protocol of McDougal et al. (2003). In a previously weighed microtube, $0.5 \mathrm{~mL}$ of an overnight culture of $S$. aureus was centrifuged at $12,000 \mathrm{rpm}$ for $50 \mathrm{~s}$. After discarding the supernatant, the microtube was weighed again and $300 \mu \mathrm{L}$ TE $(10 \mathrm{mM}$ Tris, $1 \mathrm{mM}$ EDTA, pH 8.0) plus the difference between the final and initial weight in $\mathrm{mL}$ were added. The samples were left to stand in a water bath for $10 \mathrm{~min}$ at $37^{\circ} \mathrm{C}$. After homogenization, $5 \mu \mathrm{L}$ lysostaphin $(1 \mathrm{mg} / \mathrm{mL}$ in $20 \mathrm{mM}$ sodium acetate, $\mathrm{pH} 4.5$ ) and $300 \mu \mathrm{L}$ low-melting agarose were added. The mixtures were poured into plug molds and the plugs were allowed to solidify. The plugs were then placed in $2 \mathrm{~mL}$ EC solution (6 mM Tris- $\mathrm{HCl}, 1 \mathrm{M} \mathrm{NaCl}, 100 \mathrm{mM}$ EDTA, $0.5 \%$ Brij- $58,0.2 \%$ sodium deoxycholate, $0.5 \%$ sodium lauryl sarcosinate) and incubated at $37^{\circ} \mathrm{C}$ for at least $4 \mathrm{~h}$. The EC solution was discarded and the plugs were washed four times with $2 \mathrm{~mL}$ TE for $30 \mathrm{~min}$ at room temperature.

Genomic DNA was restricted with SmaI (Fast Digest $\mathrm{SmaI}^{\circledR}$, Fermentas Life Science, Canada) in $50 \mu \mathrm{L}$ restriction buffer using half the plug. Electrophoresis was carried out in a CHEF-DR III System ${ }^{\circledR}$ (BioRad Laboratories, USA) using 1\% agarose gel (Pulsed Field Certified Agarose, BioRad Laboratories, USA) prepared in 0.5X TBE under the following running conditions: pulse time of 5 to 
$40 \mathrm{~s}$ for $21 \mathrm{~h}$; linear ramp; $6 \mathrm{~V} / \mathrm{cm}$; angle of $120^{\circ} ; 14^{\circ} \mathrm{C}$; $0.5 \mathrm{X}$ TBE as running buffer. The Lambda Ladder PFG Marker ${ }^{\circledR}$ (New England BioLabs) was used as molecular marker. The gels were stained with GelRed ${ }^{\circledR}(10,000 \mathrm{X}$ in water, Biotium, USA) for $45 \mathrm{~min}$ and photographed under UV transillumination. For analysis of similarity, the Dice correlation coefficient was calculated and a dendrogram was constructed by the UPGMA method (unweighted pair group method using arithmetic averages) using the BioNumerics ${ }^{\circledR}$ software (version 6.1; Applied Maths, Belgium).

\section{Results}

Microorganisms were detected in 169 (35.7\%) of the 473 milk samples collected from the 242 animals included in the study. Twenty (11.8\%) of the microorganisms isolated were identified as S. aureus, including 18 (90\%) strains isolated from cases of subclinical mastitis and only two $(10 \%)$ from animals without mastitis. Four of the 20 strains were isolated in the flock from Botucatu, two in the flock from Nova Odessa, and 14 in the flock from São Carlos.

\section{Antimicrobial resistance}

The mecA gene was not detected in any of the $S$. aureus strains and most isolates were susceptible to all antimicrobial agents tested, except for one strain that was resistant to tetracycline.

\section{Toxin detection}

Seven $(35 \%)$ of the $S$. aureus isolates carried one or more exotoxin genes (Table 2). Three (15\%) of these seven strains that tested positive by PCR for exotoxin genes were positive by RT-PCR. One isolate carrying the sec+tst genes expressed the two genes concomitantly, one isolate carrying the sea+seb+luk-PV genes expressed only the luk-PV gene, and the third isolate positive for the $\operatorname{sea}+\sec$ genes expressed only the $\sec$ gene.

\section{Biofilm detection}

With respect to biofilm genes (Table 3), the complete icaADBC operon was detected in one of the isolates. The

Table 2 - Detection and expression of exotoxin genes.

\begin{tabular}{lcc}
\hline Gene/expression & PCR N (\%) & RT-PCR N (\%) \\
\hline sea + seb+luk-PV/PVL & $1(5.0)$ & $1(5.0)$ \\
sea + seb & $2(10.0)$ & 0 \\
sec+tst/SEC+TSST-1 & $1(5.0)$ & $1(5.0)$ \\
sea + sec/SEC & $1(5.0)$ & $1(5.0)$ \\
Total & $7(35.0)$ & $3(15.0)$ \\
\hline
\end{tabular}

sea, seb, sec, tst, luk-pv: presence of the genes encoding toxins A, B, C, TSST-1, and Panton-Valentine leukocidin (PVL). PVL, TSST-1 and SEC: Toxin expression. N: number of isolates; \%: percentage of isolates.
Table 3 - Detection and expression of biofilm genes.

\begin{tabular}{lcc}
\hline Genes & PCR N (\%) & RT-PCRN (\%) \\
\hline$i c a A D B C$ & $1(5.0)$ & 0 \\
$i c a A+i c a D+i c a B$ & $5(25.0)$ & 0 \\
$i c a A+i c a D$ & $3(15.0)$ & 0 \\
$i c a A+i c a D+b a p$ & $3(15.0)$ & 0 \\
$i c a D+b a p$ & $1(5.0)$ & 0 \\
$i c a D$ & $3(15.0)$ & 0 \\
$i c a B$ & $1(5.0)$ & 0 \\
Total & $17(85.0)$ & 0 \\
\hline
\end{tabular}

icaA, icaD, icaB, icaC, bap: biofilm genes; $\mathrm{N}$ : number of isolates; \%: percentage of isolates.

$i c a A+i c a D+i c a B$ were concomitantly present in five isolates, icaA $+i c a D$ in six isolates, three isolates only carried the $i c a D$ gene, and one isolate only carried the icaB gene. The bap gene was detected in four (20\%) isolates, but none of the strains expressed this gene.

None of the isolates exhibited a positive result in the phenotypic test of biofilm formation on polystyrene plates.

Typing

Molecular typing by PFGE was performed on only 17 strains since three isolates from the São Carlos flock could not be typed. PFGE (Figure 1) revealed the presence of two clones, a larger one (clone 1) comprising 10 isolates (one from Nova Odessa, five from São Carlos, and four from Botucatu) and a smaller one (clone 2) comprising only two isolates from São Carlos. The remaining five isolates (one from Nova Odessa and four from São Carlos) exhibited a polyclonal profile.

With respect to virulence factors (Table 4), in clone 1 (10 isolates) only one strain carried an enterotoxin gene and the TSST-1 gene and expressed the two genes. The bap gene was detected in one isolate and the $i c a B$ gene of the $i c a A D B C$ operon was detected in five isolates, but no expression of these genes related to biofilm formation was observed.

None of the toxin genes studied was detected in clone 2 (two isolates). Regarding the genes for biofilm formation, only the bap gene was detected in two isolates by PCR, but not by RT-PCR. The genes of the icaADBC operon were not detected in any of the isolates by RT-PCR.

With respect to the virulence of $S$. aureus isolated from different flocks, it is important to highlight the detection of the sea $+\mathrm{sec}$ and $\mathrm{sec}+t s t$ genes in two strains isolated from the farm in Nova Odessa, with the expression of SEC and TSST-1 being confirmed by RT-PCR (Figure 1). In the flock from São Carlos, the $l u k-P V$ gene was detected and expressed in one isolate. Additionally, four bap genepositive isolates were from this farm and one isolate carried the complete icaADBC operon. No toxigenic S. aureus strains were isolated from the farm in Botucatu; however, 


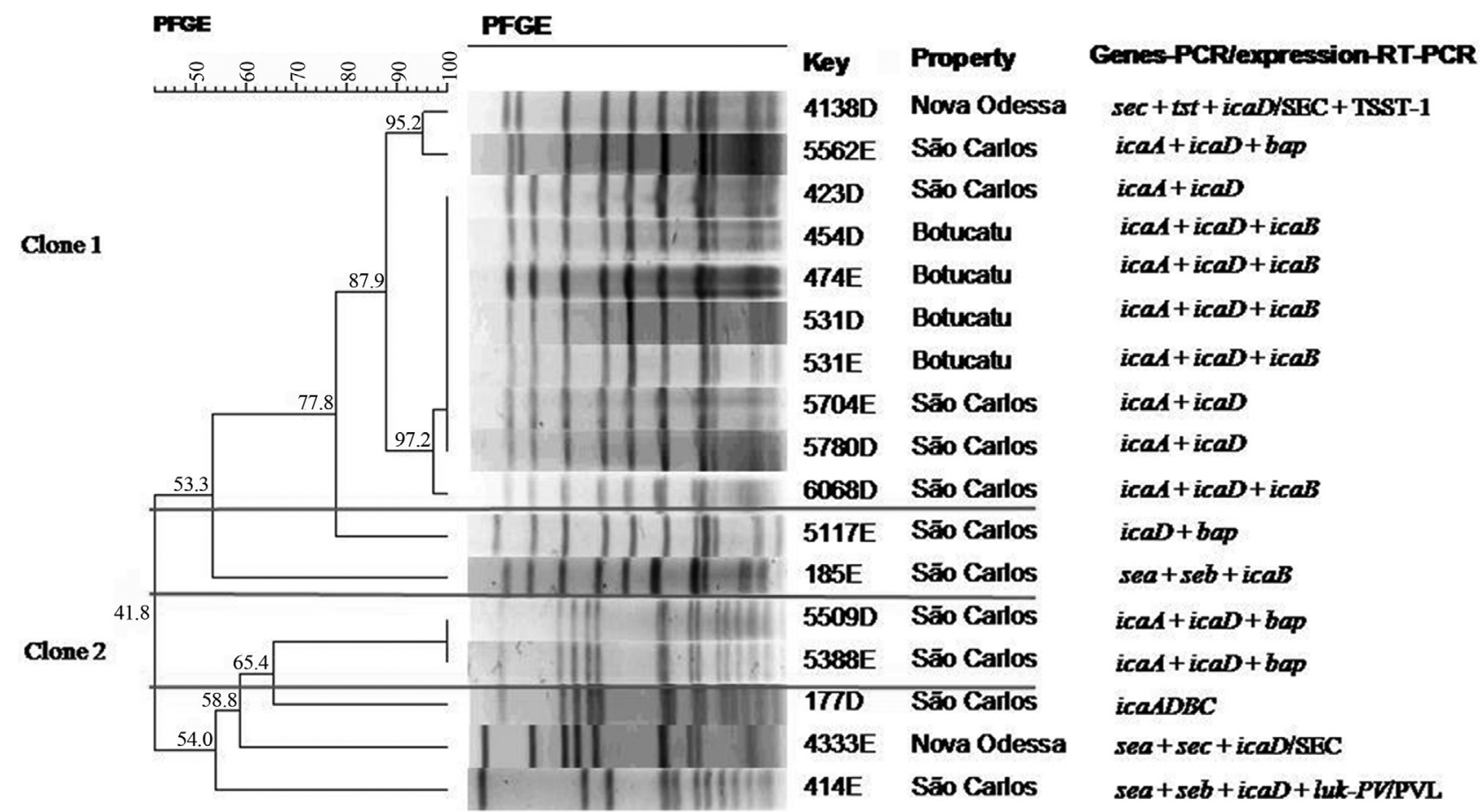

Figure 1 - Dendrogram generated by Dice analysis/UPGMA (Bionumerics, Applied Maths) of the SmaI PFGE profiles of 17 S. aureus isolates (similarity $\geq 80 \%$ ).

Table 4 - Characteristics of the $S$. aureus clones isolated from sheep milk samples.

\begin{tabular}{|c|c|c|c|c|}
\hline Clone & Toxin gene & $\begin{array}{c}\text { Toxin } \\
\text { expression }\end{array}$ & $\begin{array}{l}\text { Biofilm } \\
\text { genes }\end{array}$ & $\begin{array}{l}\text { Biofilm } \\
\text { expression }\end{array}$ \\
\hline \multirow[t]{6}{*}{1 (10 isolates) } & sea $(0)$ & SEA (0) & icaA (9) & $i c a A(0)$ \\
\hline & $\operatorname{seb}(0)$ & SEB (0) & $i c a D(10)$ & $i c a D(0)$ \\
\hline & $\sec (1)$ & SEC (1) & $i c a B(5)$ & $i c a B(0)$ \\
\hline & sed $(0)$ & SED (0) & $i c a C(0)$ & $i c a C(0)$ \\
\hline & tst (1) & TSST-1 (1) & bap (1) & bap $(0)$ \\
\hline & $l u k-\mathrm{PV}(0)$ & PVL (0) & & \\
\hline \multirow[t]{6}{*}{2 (2 isolates) } & sea $(0)$ & SEA (0) & $i c a A(2)$ & $i c a A(0)$ \\
\hline & $\operatorname{seb}(0)$ & SEB (0) & $i c a D(2)$ & $i c a D(0)$ \\
\hline & $\sec (0)$ & SEC (0) & $i c a B(0)$ & $i c a B(0)$ \\
\hline & $\operatorname{sed}(0)$ & SED (0) & $i c a C(0)$ & $i c a C(0)$ \\
\hline & tst $(0)$ & TSST-1 (0) & bap (2) & bap $(0)$ \\
\hline & $l u k-\mathrm{PV}(0)$ & PVL (0) & & \\
\hline
\end{tabular}

the icaADC genes were detected in four strains isolated from animals of this flock.

\section{Discussion}

S. aureus is a versatile microorganism that causes infection in different hosts. Moreover, this bacterium is one of the most important pathogens in the etiology of infectious mastitis in cows, goats, and sheep, causing chronic in- fection of the mammary tissue that is difficult to treat (Aires-de-Souza et al., 2007). In the present study, S. aureus was identified in $20(11.8 \%)$ milk samples collected from sheep with subclinical mastitis.

The mecA gene was not detected in any of the $S$. aureus strains studied. Vyletelová et al. (2011) also did not find the mecA gene in $S$. aureus strains isolated from sheep milk, whereas the gene was detected in $20(6.1 \%)$ S. aureus strains isolated from cow milk. According to Zafalon et al. (2012), S. aureus strains that carry oxacillin resistance mediated by the mecA gene are generally more resistant to other antibiotics than oxacillin-sensitive microorganisms. In the present study, antimicrobial susceptibility testing revealed only one $S$. aureus isolate that was resistant to tetracycline. The remaining isolates were susceptibility to all drugs tested. Similar results have been reported by Vyletelová et al. (2011) for S. aureus isolates from sheep. Pengov and Ceru (2003), investigating S. aureus isolates obtained from sheep milk samples, demonstrated high rates of susceptibility to the drugs tested. A resistance rate of $6.3 \%$ was only observed for penicillin and ampicillin.

Intramammary infections caused by S. aureus can have severe consequences for human health because of the production of toxins by this microorganism. These toxins are secreted and remain stable in milk, causing food poisoning (Balaban and Rasooly, 2000; Fagundes and Oliveira, 2004). In the present study, seven isolates carried at least one enterotoxin gene or the TSST-1 gene, with the seb gene being the most frequent enterotoxin followed by the sea 
and sec genes. The sed gene was not detected in any of the isolates. In contrast, the sec gene was the most frequent in the study of Scherrer et al. (2004). The authors detected this gene in $123(64.4 \%)$ of $191 \mathrm{~S}$. aureus strains isolated from milk samples of sheep and goats, followed by seg (16.2\%), sea $(14.6 \%)$, sej $(13.6 \%)$, sei $(12.6 \%)$, seb $(2.1 \%)$, and sed (2.1\%). In the literature, sea and seg (Scherrer et al., 2004; Wang et al., 2009) and sec, sed, seg and sei (Zecconi et al., 2006) are the genes most frequently detected in $S$. aureus isolated from animals.

Although the $s e b$ gene was the most frequent, it was not expressed in any of the $S$. aureus isolates. Only two $(10 \%)$ isolates expressed the sec gene and one (5\%) the tst gene. Enterotoxins A and D are the toxins most frequently implicated in outbreaks of food poisoning (Ertas et al., 2010). However, the present results demonstrate the importance of enterotoxin $\mathrm{C}$ and TSST-1 in strains isolated from sheep. Enterotoxin $\mathrm{C}$ has been frequently detected in cases of clinical mastitis in cattle, goats and sheep (Jones and Wieneke, 1986). In England, Bone et al. (1989) reported cases of food poisoning caused by the consumption of sheep milk and cheese. Analysis of the cheese samples showed the presence of enterotoxins. Further analysis of milk and cheese samples led the authors to conclude that food contamination with $S$. aureus did not occur during production, but was the result of infection of the milkproducing animals.

The exotoxin Panton-Valentine leukocidin (PVL) was detected in only one strain and its expression was confirmed. PVL is one of the most important virulence factors produced by $S$. aureus, contributing to the pathogenicity of this microorganism. This toxin is associated with different diseases in humans, such as pneumonia and necrotizing dermatitis (Giudice et al., 2009). The luk-PV gene has also been identified in $S$. aureus strains isolated from cases of mastitis (Zecconi et al., 2006; Aires-de-Souza et al., 2007; Unal et al., 2012). However, this is the first report showing the expression of this toxin in $S$. aureus isolated from sheep.

Among the different $S$. aureus virulence factors studied, biofilm formation in isolates obtained from cases of sheep mastitis is a poorly investigated aspect. The $i c a A D B C$ operon is responsible for the synthesis of polysaccharide intercellular adhesin (PIA), the main component of the staphylococcal biofilm (Otto, 2008). In the present study, only one isolate carried the complete icaADBC operon, whereas other genes of the operon, mainly icaA + $i c a D$, were detected in most isolates (Table 3). However, none of the isolates expressed the ica genes detected. The bap gene encodes a protein that plays an important PIAindependent role in biofilm formation (Cucarella et al., 2004). This gene was detected in four strains (Table 4). However, RT-PCR showed no expression of this gene in any of the $S$. aureus isolates. The bap gene is usually not detected and its presence has only been reported in a few $S$. aureus strains isolated from cases of bovine subclinical mastitis (Cucarella et al., 2001). The present results differ from those reported by Tel et al. (2012) who analyzed 110 $S$. aureus strains isolated from cases of sheep clinical mastitis. The isolates did not carry the bap gene, but were positive for the icaA and icaD genes. According to Aguilar et al. (2001), most $S$. aureus strains isolated from mastitis cases are surrounded by a biofilm layer that facilitates adhesion and colonization of the mammary gland epithelium. However, the 20 isolates from sheep studied here did not express the genes studied (icaADBC and bap).

Typing of $17 \mathrm{~S}$. aureus strains revealed the presence of a common clone on the three farms studied. The characterization of the genetic diversity of $S$. aureus is important to understand the pattern of dispersion of the pathogen. The results showed no major heterogeneity among $S$. aureus strains, with half the isolates belonging to a single clone. With respect to the virulence profile of these strains, only one expressed the sec and tst genes, while the other strains expressed none of the factors studied. These findings suggest that other virulence factors are related to the capacity of this clone to spread among flocks and to successfully establish an infection in the mammary gland of sheep, causing mastitis. The $s e c$ and $t s t$ genes are located on a plasmid and pathogenicity island, respectively, and can be transferred from one bacterium to another. The presence of these genes in one strain suggests that this clone, which is able to spread among the flocks studied, probably acquired these virulence genes from other staphylococci, rendering it more virulent.

\section{Conclusion}

Most of the $S$. aureus strains identified were isolated from cases of subclinical mastitis. Only two isolates did not cause infection, a finding demonstrating the importance of $S$. aureus in the etiology of sheep mastitis. All S. aureus strains isolated from the three flocks showed high susceptibility to the drugs tested. None of the isolates was a biofilm producer, indicating that biofilm formation was not a virulence factor causing infection by these strains. However, a toxigenic potential was demonstrated for some of the isolates, which expressed SEC, TSST-1 and PVL. A clone that had spread among sheep flocks was identified among the $S$. aureus strains isolated from sheep milk. In addition, the presence and expression of the sec and tst genes in one strain of this clone suggest the possible acquisition of virulence genes by this clone, a fact that is important for animal health and food hygiene.

\section{Acknowledgments}

The authors thank the Fundação de Amparo a Pesquisa do Estado de São Paulo and Conselho Nacional de Desenvolvimento Científico e Tecnológico (CNPq) for financial support. 


\section{References}

Aguilar B, Amorena B, Iturralde M (2001) Effect of slime on adherence of Staphylococcus aureus isolated from bovine and ovine mastitis. Vet Microbiol 78:183-191.

Aires-de-Sousa M, Parente CESR, Vieira-da-Mota OV et al. (2007) Characterization of Staphylococcus aureus isolates from buffalo, bovine, ovine, and caprine milk samples collected in Rio de Janeiro State, Brazil. Appl Environ Microbiol 73:3845-3849.

Al-Majali AM, Jawabreh S (2003) Period prevalence and etiology of subclinical mastitis in Awassi sheep in southern Jordan. Small Rum Res 47:243-248.

Arciola CR, Gamberini S, Campoccia D et al. (2005) A multiplex PCR method for the detection of all five individual genes of ica locus in Staphylococcus epidermidis. A survey on 400 clinical isolates from prosthesis-associated infections. J Biomed Mater Res A 75:408-413.

Argudín MA, Mendoza MC, Rodicio MR (2010) Food poisoning and Staphylococcus aureus enterotoxins. Toxins 2:17511773.

Balaban N, Rasooly A (2000) Staphylococcal enterotoxins: a review. Int J Food Microbiol 61:1-10.

Bergonier D, Cremoux R, Rupp R et al. (2003) Mastitis of dairy ruminants. Vet Res 34:689-716.

Bone FJ, Bogie D, Morgan-Jones SC (1989) Staphylococcal food poisoning from sheep milk cheese. Epidemiol Infect 103:449-458.

Christensen GD, Simpson WA, Yonger JJ et al. (1985) Adherence of coagulase-negative Staphylococci to plastic tissue culture plates: a quantitative model for the adherence of Staphylococci to medical devices. J Clin Microbiol 22: 996-06.

Clinical and Laboratory Standards Institute (2012) Performance Standards for Antimicrobial Susceptibility Testing: Approved Standard M100-S22.CLSI, Wayne, PA, USA.

Contreras A, Sierra D, Sanchez A et al. (2007) Mastitis in small ruminants. Small Ruminant Res 68:145-153.

Cucarella C, Solano C, Valle J et al. (2001) Bap, a Staphylococcus aureus surface protein involved in biofilm formation. J Bacteriol 183:2888-2896.

Cucarella C, Tormo MA, Úbeda C et al. (2004) Role of biofilmassociated protein Bap in the pathogenesis of bovine Staphylococcus aureus. Infect Immun 72:2177-2185.

Cunha MLRS, Sinzato YK, Silveira LVA (2004) Comparison of methods for the identification of coagulase-negative Staphylococcus. Mem Inst Oswaldo Cruz 99: 855-860.

Ertas N, Gonulalan Z, Yildirim Y et al. (2010) Detection of Staphylococcus aureus enterotoxins in sheep cheese and dairy desserts by multiplex PCR technique. Int J Food Microbiol 142:74-77.

Fagundes H, Oliveira CAF (2004) Infecções intramamárias causadas por Staphylococcus aureus e suas implicações em saúde pública. Cienc Rural 34:1315-132.

Giudice P, Blanc V, de Rougemont A et al. (2009) Primary skin abscesses are mainly caused by Panton-Valentine leukocidin-positive Staphylococcus aureus strains. Dermatology 219:299-202.

Johnson WM, Tyler SD, Ewan EP et al. (1991) Detection of genes for enterotoxins, exfoliative toxins, and toxic shock syndrome toxin 1 in Staphylococcus aureus by the polymerase chain reaction. J Clin Microbiol 29:426-430.
Jones TO, Wieneke AA (1986) Staphylococcal toxic shock syndrome. Vet Rec 119:34-45.

Kumar R, Yadav BR, Singh RS (2010) Genetic determinants of antibiotic resistance in Staphylococcus aureus isolates from milk of mastitic crossbred cattle. Curr Microbiol 60:379386.

Lina G, Piemont Y, Godail-Gamot F et al. (1999) Involvement of Panton-Valentine leukocidin-producing Staphylococcus aureus in primary skin infections and pneumonia. Clin Infect Dis 29:1128-1132.

McDougal LK, Steward CD, Killgore GE et al. (2003) Pulsedfield gel electrophoresis typing of oxacillin-resistant Staphylococcus aureus isolates from the United States: Establishing a national database. J Clin Microbiol 41:5113-5120.

McDougall S, Murdough P, Pankey W et al. (2001) Relationship among somatic cell count, California mastitis test, impedance and bacteriological status of milk in goats and sheep in early lactation. Small Ruminant Res 40:245-254.

Moroni P, Pisoni G, Varisco G et al. (2007) Effect of intramammary infection in Bergamasca meat sheep on milk parameters and lamb growth. J Dairy Res 74:340-344.

Murakami K, Minamide K, Wada K et al. (1991) Identification of methicillin-resistant strains of staphylococci by polymerase chain reaction. J Clin Microbiol 29:2240-2244.

Oliveira A, Cunha MLRS (2010) Comparison of methods for the detection of biofilm production in coagulase-negative staphylococci. BMC Res Notes 3:260.

Otto M (2008) Staphylococcal biofilm. Curr Top Microbiol Immunol 322:207-228.

Peacock SJ, Moore CE, Justice A et al. (2002) Virulent combinations of adhesin and toxin genes in natural populations of Staphylococcus aureus. Infect Immun 70:4987-4996.

Pengov A, Ceru S (2003) Antimicrobial drug susceptibility of Staphylococcus aureus strains isolated from bovine and ovine mammary glands. J Dairy Sci 86:3157-3163.

Rohde H, Burandt EC, Siemssen N et al. (2007) Polysaccharide intercellular adhesin or protein factors in biofilm accumulation of Staphylococcus epidermidis and Staphylococcus aureus isolated from prosthetic hip and knee joint infections. Biomaterials 28:1711-1720.

Sabour PM, Gill JJ, Lepp D et al. (2004) Molecular Typing and Distribution of Staphylococcus aureus Isolates in Eastern Canadian Dairy Herds. J Clin Microbiol 42:3449-3455.

Santos FGP, Mota RA, Silveira Filho VM et al. (2003) Tipagem molecular de Staphylococcus aureus isolados de leite de vacas com mastite subclínica e equipamentos de ordenha procedentes do estado do Pernambuco. Revista Napgama 6:19-23.

Santos RA, Mendonça CL, Afonso JA et al. (2007) Aspectos clínicos do leite em ovelhas com mastite induzidas experimentalmente com Staphylococcus aureus. Pesq Vet Bras 27:6-12.

Schalm OW, Noorlander DO (1957) Experiments and observations leading to development of the California Mastitis Test. J Am Vet Med Assoc 30:199-207.

Scherrer D, Corti S, Muehlherr JE et al. (2004) Phenotypic and genotypic characteristics of Staphylococcus aureus isolates from raw bulk-tank milk samples of goats and sheep. Vet Microbiol 101:101-107.

Tel OU, Aslantas O, Keskey K et al. (2012) Investigation of the antibiotic resistance and biofilm of Staphylococcus aureus 
strains isolated from gangrenous mastitis of ewe. Acta Vet Hung 60:189-197.

Unal N, Askar S, Macun HC et al. (2012) Panton-Valentine leukocidin and some exotoxins of Staphylococcus aureus and antibiotic susceptibility profiles os staphylococci isolated from milk of small ruminants. Trop Anim Health Prod 44:573-579.

Vautor E, Cockfield J, Le Marechal C et al. (2009) Difference in virulence between Staphylococcus aureus isolates causing gangrenous mastitis vs. subclinical mastitis in a dairy sheep flock. Vet Res 40:56.

Vyletelová M, Vlková H, Manga I (2011) Occurrence and characteristics of methicillin resistant Staphylococcus aureus and methicillin resistant coagulase-negative staphylococci in raw milk manufacturing. Czech J Food Sci 29: 11-16.

Wang SC, Wu CM, Xia et al. (2009) Distribution of superantigenic toxin genes in Staphylococcus aureus isolates from milk samples of bovine subclinical mastitis cases in two major dairy production regions of China. Vet Microbiol 137:276-281.

Wang Y, Wu CM, Lu LM et al. (2008) Macrolide-lincosamideresistant phenotypes and genotypes of Staphylococcus aureus isolated from bovine clinical mastitis. Vet Microbiol 130:118-125.

Zafalon LF, Verissimo CJ, Mamizuka EM et al. (2012) Estafilococos resistentes a oxacilina isolados dos casos de mastite subclinica em ovinos. Arq Inst Biol 79:1-7.

Zecconi A, Cesaris L, Liandris E et al. (2006) Role of several Staphylococcus aureus virulence factors on the inflammatory response in bovine mammary gland. Microb Pathogenesis 40:177-183.

Associate Editor: Odir Antonio Dellagostin

All the content of the journal, except where otherwise noted, is licensed under a Creative Commons License CC BY-NC. 